\title{
FUNKCIONALISMUS - MEZIVÁLEČNÝ FENOMÉN NEBO STYL PŘESAHUJÍCÍ VÁLKU I SORELU?
}

\author{
ELIŠKA PODHOLOVÁ VARYŠOVÁ \\ Ústav pro dějiny umění Filozofické fakulty Univerzity Karlovy \\ elvar@seznam.cz
}

\begin{abstract}
Functionalism in architecture - the interwar phenomenon or the style overcoming war and socialist realism?

The article is focused on the continuing of functionalist style in Czechoslovak architecture after second war. The architectural development of that time could be read as a continual stream from the interwar functionalism, through the late functionalism in 1945-1948 and in the rise of modernism in the end of the 1950s after the socialist realism period, which led to the last period of modernism - and functionalism - in the 1960s.

Keywords: Architectural modernism - late Functionalism - International style - postwar Czechoslovak architecture - Brussels Expo 1958
\end{abstract}

Architektonický funkcionalismus je neodmyslitelně spjat s meziválečným obdobím. Většina publikací, statí a monografií určuje jeho začátek přibližně v polovině dvacátých let (některé dokonce rokem 1920) a ukončuje ho rokem 1939 se začátkem války (př́ípadně 1942 se stavební uzávěrou). ${ }^{1}$ Funkcionalismus a meziválečná architektura jsou tedy často brány jako synonyma. Architektura čtyřicátých let je většinou řazena spíše do druhé poloviny století, právě kvưli přerušení válkou a krátkému poválečnému vývoji, nedílně spojenému s padesátými lety. Válka tedy představuje bariéru nejen v samotném vývoji architektury, ale také v historickém vnímání tohoto vývoje.

Zatímco za války se architekti věnovali především teorii a revizi meziválečného stylu, s jejím skončením se začalo opět stavět a v krátkém období dvouletky se ve funkcionalistické architektuře projevila snaha přizpůsobit styl novým požadavkům a vyřešit problémy, kritizované už od konce třicátých let. Období mezi léty 1945 a 1948 bývá tedy bráno jako doznívání funkcionalismu, ${ }^{2}$ ač v souhrnných článcích o funkcionalismu už většinou nebývá zahrnuto. S rokem 1948 přichází další násilné ukončení funkcionalismu, které už po nástupu socialistického realismu vypadá jako konečné. Nástup komunismu a padesátá léta tak představují ve vývoji i jeho vnímání stejně silnou bariéru jako válka.

1 Rostislav Švácha, Od moderny k funkcionalismu, Praha 1995. - Český funkcionalismus 1920-1940: Architektura (katalog výstavy), Uměleckoprůmyslové muzeum v Praze, text Alena Vondrová, Praha 1978. - Vladimír Šlapeta - Václav Jandáček, Stavební kniha: Český funkcionalismus, Brno 2004, a další publikace.

2 Zdeněk Lukeš - Jan Sedlák, Doznívání funkcionalismu, in: Miroslav Baše et al., Česká architektura 1945-1995, Praha 1995, s. 21-28. 
Některé stavby navržené v pozdně funkcionalistickém stylu před nástupem komunismu se však dokončují ještě v první polovině padesátých let, zatímco po polovině této dekády se již opět na scénu vrací modernismus. Návrat modernismu v československé architektuře je tradičně spojován s pavilonem na Expo $58 \mathrm{v}$ Bruselu od trojice architektů Cubra, Hrubého a Pokorného a s vlivy zahraničního internacionálního stylu. ${ }^{3}$ Architektura takzvaného bruselského stylu však čerpá také z domácí funkcionalistické tradice, ostatně mnoho architektů meziválečného období v té době stále aktivně projektuje nebo učí. Bruselský styl a vliv internacionálního miesovského stylu pozvolně odeznívá v šedesátých letech s nástupem nové generace architektů a vlivů technicismu, skulpturalismu a brutalismu.

Dá se tedy brát pozdní modernismus přelomu padesátých a šedesátých let jako definitivní vyčerpání a ukončení funkcionalistické éry? Je možné i v české architektuře najít kontinuitu vývoje i přes přerušení válkou a érou socialistického realismu?

Pokud se podíváme podrobněji na ony zlomové body ve vývoji funkcionalismu, uvidíme určitou neukončenost $\mathrm{v}$ řešení problémů stylu, způsobenou především politickými okolnostmi, nikoli vyčerpáním námětu. Na konci třicátých let byl funkcionalismus v Československu rozšířeným stylem, jeho východiska i forma však narážely na stále větší problémy a kritiku - dogmatická orientace na funkci, přísně zónový urbanismus, spory mezi emocionálními a vědeckými funkcionalisty o psychologické působení architektury na obyvatele či uživatele, problematika univerzálních staveb bez vazby na konkrétní místo a podobně. Zásadní diskusí byla monumentalita $v$ architektuře, která ve věcně navrhovaném meziválečném funkcionalismu zcela chyběla. $\mathrm{V}$ teoretických statích a poválečné tvorbě se ji tak architekti snažili zapracovat do funkcionalistických forem a tvarosloví. Někteři funkcionalisté se začali přiklánět k modernímu klasicismu. Stejným způsobem se architekti museli vypořádat při práci s historickým kontextem, v památkové péči a při práci s regionální architekturou. ${ }^{4}$

Válečné přerušení stavební produkce dalo architektům čas na reflexi meziválečné architektury a její revizi, na řešení problémů, které palčivě vyvstávaly již v průběhu třicátých let. Válka tedy ve vývoji funkcionalismu jistě představuje přerušení samotné stavební činnosti, ale nikoliv myšlenkového a názorového vývoje.

Po osvobození se teoretické výsledky diskuze mohly promítnout do praxe. V krátkém období takzvané dvouletky, tedy dvouletého plánu na obnovu ČSR v letech 1947 až 1948, se horečně stavělo - plán byl zaměřen především na obnovu infrastruktury, ale mělo vzniknout také množství nových bytů, především u průmyslových oblastí. ${ }^{5}$ Nejznámějším pražským příkladem je sídliště Solidarita od architektů Františka Jecha, Hanuše Majera a Karla Storcha (realizace mezi léty 1947 až 1961) ${ }^{6}$ s řádkovým funkcionalistickým uspořádáním, hrubými fasádami a sedlovými střechami - už zde se projevuje př́klon k mohutnějším formám, plastičtější členění a důraz na „výraz” architektury (termín Karla

3 Martin Strakoš, Po sorele brusel, kov, sklo, struktury a beton: Kapitoly o architektuře a umění 50. a 60. let 20. století od Bruselu po Ostravu, Ostrava 2014. - Vít Havránek et al., Bruselský sen: Československá účast na světové výstavě Expo 58 v Bruselu a životní styl 1. poloviny 60. let (katalog výstavy), Galerie hlavního města Prahy, Moravská galerie v Brně, Praha 2008.

4 Vladimír Czumalo, Ceská teorie architektury v letech okupace, Praha 1991.

5 Rostislav Švácha, Architektura čtyřicátých let, in: Rostislav Švácha - Marie Platovská (eds.), Dějiny českého výtvarného umění V, 1939 -1958, Praha 2005, s. 31-74.

6 Barbora Spičáková (ed.), Sídliště Solidarita, Kostelec nad Černými lesy 2014. 
Honzíka pro větší psychologický účinek architektury). Sedlové střechy ukazují na určitou snahu o polidštění architektury, ale také nové hledání tradice. Sídliště se stavěla také v Kladně (Rozdělov - Josef Havlíček, Karel Filsak, Václav Hilský a další, dokončeno až v šedesátých letech); nebo ve Zlíně (Morýsovy domy ve Zlíně od Miroslava Drofy a další). Zároveň se v pozdním funkcionalismu uplatňovaly také křivky, půdorysy ve tvaru písmene ypsilon, plastičtější a dekorativnější prvky jako zábradlí či soustavy bohatě členěných oken (nemocnice od Bedřicha Rozehnala ${ }^{7}$ v Brně-Černých Polích, Kroměříži, Novém Městě na Moravě či v Dačicích nebo kotelna nemocnice od Víta Obrtela v Jičíně.

Nové inspirační zdroje se objevovaly také ve státech se stejnými nebo obdobnými sociálními aspiracemi jako poválečné Československo. Pozornost se obracela k anglické sociální architektuře a také architektuře skandinávské, jejíž ohlasy můžeme najít například v tvorbě Jaroslava Fragnera a v jeho řešení rekonstrukce Karolina ${ }^{8}$ (organický dřevěný strop auly inspirovaný Alvarem Aaltem). Ještě více se uplatňoval vliv střídmého švédského funkcionalismu, který zachovával tradiční národní a lidové prvky jako sedlové střechy a podobně (návštěva Stockholmu měla prŕmý vliv také na autory sídliště Solidarita).

Dalo by se tedy říci, že přirozeným vyrovnáváním se s problémy funkcionalismu, řešením jeho neduhů a přijímáním nových podnětů a jejich vstřebáváním se styl pomalu blí̌zil svému konci. Stejní autoři, kteří pracovali v meziválečném období, hledali nová východiska stylu a přidávala se $\mathrm{k}$ nim nová generace, která studia dokončila těsně před válkou nebo těsně po ní. Skutečně se však v tomto bodě funkcionalismus přirozeně vyčerpal a skončil? Nebo můžeme nástup sorely vnímat jako další násilné přerušení činnosti, tentokrát praktické i teoretické?

Proč se vůbec nabízí tato otázka pokračování stylu? Pokud srovnáme vývoj v ČSR se situací v zahraničí - tedy alespoň na Západě -, funkcionalismus se zde po válce potýkal s podobnými otázkami a problémy jako v Československu. Zatímco někteří autoři pokračovali v tradici internacionálního stylu a v čele s Miesem van der Rohe ho přivedli v padesátých letech $\mathrm{k}$ vrcholu, kdy se pak začal vyčerpávat a ustupovat jiným tendencím, další představitelé, především Le Corbusier, už od konce tř̌icátých let začali postupně měnit svůj výraz k brutalismu, používání pohledového betonu, větší plasticitě, skulpturálnímu výrazu staveb. ${ }^{9}$ Zatímco mladší generace architektů si hledala svůj vlastní výraz, transformace funkcionalismu v tvorbě meziválečných architektů probíhala pozvolněji. Z internacionálního stylu jako přímého pokračovatele funkcionalismu se stal úspěšný a používaný styl, který dosáhl svého vzepětí a postupně se vyprázdnil a přirozeně ukončil - at' už př́klonem k jiným tendencím, nebo smrtí hlavních protagonistů. Podobný vývoj mohl nepochybně nastat i v ČSR, ale zabránila tomu politická situace.

S únorem 1948 samozřejmě neutichla stavební činnost. S novým politickým režimem však přišlo sloučení architektonických ateliérů do centrálních projektových kanceláří.

7 Petr Pelčák - Vladimír Šlapeta - Ivan Wahla (eds.), Bedřich Rozehnal, 1902-1984 (katalog výstavy), Obecní dům Brno 2009.

8 Jaroslav Fragner: Náčrty a plány (katalog výstavy), texty Jiří T. Kotalík - Rostislav Švácha - Jiř́i Novotný, Galerie Jaroslava Fragnera, Praha 1999.

9 Strakoš, Po sorele brusel (pozn. 3). - Rostislav Švácha, Česká architektura 1956-1963, in: Marie Judlová (ed.), Ohniska znovuzrození: České umění 1956-1963 (kat. výst.), Galerie hlavního města Prahy, Ústav dějin umění AV ČR, Praha 1994, s. 241-258. - Rostislav Svácha, Architektura 1958-1970, in: Rostislav Švácha - Marie Platovská (eds.), Dějiny českého výtvarného umění [VI/1], 1958/2000, Praha 2007, s. 31-69. 
Novým stylem se stal socialistický realismus, sorela, a vzorem sovětská architektura. ${ }^{10}$ Svobodná tvorba, at projektová, nebo teoretická, byla prakticky vyloučena - nová ideologie byla vynucována státním aparátem, navíc soukromá stavební produkce s novým zř́zením zanikla. Architekti tedy byli svou prací na státu závislí. Z meziválečného funkcionalismu se stal buržoazní kosmopolitní styl, známka nenáviděného kapitalismu - jako inspirační zdroj byla stejně západní kapitalistická architektura zapovězena.

Mnoho projektů, připravených či rozestavěných ještě během dvouletky, ${ }^{11}$ bylo přesto za nového režimu dostavováno, někdy s většími či menšími úpravami. Pozdně funkcionalistické stavby tak byly realizovány i na začátku padesátých let, například dětská nemocnice v Brně-Černých Polích od Bedřicha Rozehnala, obdivovaná i v zahraničí nejen pro svou funkčnost, ale i pro funkcionalistickou formu, s ústředním přijímacím atriem s ochozem a s lưžkovým křídlem na půdorysu písmene ypsilon a se střídáním nízké a vysoké hmotové skladby (vystavěna v letech 1948 až 1953). ${ }^{12}$ Dalším dostavovaným pozdně funkcionalistickým dílem byl koldům v Litvínově (Evžen Linhart, Václav Hilský, 1948-1958), ${ }^{13}$ kde se realizovala jen část zamýšleného areálu, nebo již zmíněné sídliště Solidarita.

S novým oficiálním stylem se změnila i skladba realizujících architektů. Mnoho funkcionalistů, především starší generace, bylo propuštěno ze svých míst na vysokých školách, někteří uvězněni a někteří dotlačeni svými kritiky $\mathrm{k}$ veřejné sebekritice na půdě sjezdu Svazu architektů. Novou architektonickou elitou (ve smyslu projektujících architektů) se stala mladší generace architektů-stalinistů. Ve stylu socialistického realismu nicméně projektovalo i mnoho starších architektů a prominenty režimu se stali levicově orientovaní architekti a zastánci nového stylu jako Jiří Kroha. Na druhou stranu někteří bývalí funkcionalisté stále vyučovali, at už Jaroslav Fragner v Praze, nebo Bohuslav Fuchs a Bedřich Rozehnal v Brně. Minimálně Rozehnal přitom funkcionalismus nikdy neopustil.

Kromě přísné regulace architektonického stylu přišla také regulace inspiračních zdrojů. ${ }^{14}$ Hlavním zdrojem se samozřejmě stala Moskva a sovětská architektura a publikování jiných zahraničních staveb - natožpak modernistických - bylo omezeno. S orientací na Sovětský svaz padla i inspirace sociální architekturou Anglie a Skandinávie. Obrat nastal kolem poloviny padesátých let, kdy se po Chruščovově kritickém projevu na sjezdu sovětských architektů a stavitelů (1954) proti zbytečnostem v architektuře začali architekti odklánět od socialistického realismu a hledali novou inspiraci pro střídmější klasicizující styl. Tou se stala především racionalistická tvorba francouzského architekta Augusta Perreta. ${ }^{15}$ Vliv západních architektů, at už Perreta, či Le Corbusiera, byl přesto stále nežádoucí, kromě formy (u Le Corbusiera přímo zvrácené a kapitalistické) bylo problémem

10 Radomíra Sedláková (ed.), Sorela. Česká architektura padesátých let (kat. výst.), Národní galerie v Praze 1994. - Strakoš, Po sorele brusel (pozn. 3). - Pavel Halík, Architektura padesátých let, in: Švácha Platovská (eds.) (pozn. 5), s. 293-328.

11 Švácha, Architektura čtyřicátých let (pozn. 5). - Lukeš - Sedlák (pozn. 2). - Radomíra Sedláková, Padesátá léta, in: Baše (pozn. 2), s. 29-38.

12 Pelčák - Šlapeta- Wahla (pozn. 7). - Bedřich Rozehnal, Výstavba dětské hospitalisace v Brně: Projekt státní oblastní nemocnice v Brnè, oddělení pro nemoci dětské, Brno 1949.

13 Švácha, Česká architektura 1956-1963 (pozn. 9).

14 Ibidem. - Strakoš, Po sorele brusel (pozn. 3).

15 Ibidem. 
také to, že ani jeden nebyl členem komunistické strany. Cíle těchto architektů tedy byly odlišné od cílů zamýšlené československé architektury. To se však netýkalo vlivu nové brazilské architektury Oscara Niemeyera, ${ }^{16}$ který v padesátých letech navštívil ČSR a později byly jeho stavby publikovány v tisku. Niemeyer byl totiž i přes individualistické rysy své architektury (a vlivy Le Corbusiera ve své tvorbě) hrdým členem komunistické strany Brazílie. Po dalším Chruščovově projevu, na sjezdu komunistické strany v roce 1956, kde sovětský předák odsoudil „kult osobnosti“, se od sorely v ČSR upustilo úplně a nový socialistický styl se hledal naplno. V Architektuře ČSR začaly být postupně otiskovány i zahraniční stavby - např́klad díla zmíněného Niemeyera či dokonce Le Corbusiera, anebo nový palác UNESCO od Marcela Breuera, Bernarda Zehrfusse a Piera Luigiho Nerviho (1957), př́padně Nerviho římské stadiony, samozřejmě s náležitě kritickými texty odsuzujícími individualismus a skulpturalismus.

Nové hledání stylu v roce 1956 nepochybně nejlépe vystihuje soutěž na pavilon Expo $58 \mathrm{v}$ Bruselu. ${ }^{17}$. Většina soutěžních projektů představovala lehce rozpačité variace pozdního funkcionalismu kombinovaného s monumentálními prvky. Vyzváni přitom byli především osvědčení architekti starší generace - tedy funkcionalisté (Fragner, Fuchs, Hrubý/Cubr/Pokorný a další). Jak údajně řekl architekt Pavel Smetana (žák Gočára a v letech 1945 až 1970 profesor na Umprum) v roce 1956: „Tak ted” mưžeme zase dělat funkcionalismus“. 18

Právě ono opětovné zapojení starší generace architektů i modernistická forma plánovaného pavilonu pro Brusel ukazují na propojení pozdního modernismu přelomu padesátých a šedesátých let s poválečným i meziválečným funkcionalismem. Bruselský pavilon od architektů Hrubého, Cubra a Pokorného nepředstavoval žádný architektonický ani tvarový experiment. Šlo o velice kultivovanou stavbu, kombinaci funkcionalistické tradice a až klasicizujícího uspořádání s čestnými dvory. Formově byl nepochybně nejzajímavější objekt restaurace. Posun od meziválečného i poválečného funkcionalismu se projevil především $\mathrm{v}$ materiálech, $\mathrm{v}$ jantarové mozaice na panelech jednotlivých pavilonů a v celoprosklených spojovacích koridorech, ale právě také v dodání monumentality, která se jako téma ve funkcionalistické diskusi objevovala od třicátých let. Pestrobarevné řešení expozic s použitím kosých tvarů a nových materiálů přerostlo vzápětí v takzvaný bruselský styl. ${ }^{19}$ Šlo však především o vizuální a interiérovou kulturu. Architektura bruselského stylu představovala pozdně funkcionalistické formy s obohacením o závěsové stěny, mozaiky, novou barevnost a propojení interiérového zařízení s celkem do Gesamtkunstwerku. Objevovaly se zde také prvky labilních šikmých střech a markýz.

Vymezení bruselského stylu v sobě nicméně většinou nese i inspiraci ostatními pavilony na bruselské výstavě a tedy zahraničním internacionálním stylem i dalšími tendencemi (technicismem, brutalismem a skulpturalismem), jak to vystihl Martin Strakoš: „kov, sklo a beton “ ${ }^{20}$ Tyto tendence se začaly následně odrážet i v československé produkci, nejprve ve velice umírněných a střídmých formách. U funkcionalistů vidíme posun v my-

16 Ibidem.

17 Ibidem. - Martin Strakoš, Architektura Expo 58 v Bruselu a československý pavilon, in: Havránek et al., Bruselský sen (pozn. 3), s. 88-107. - Švácha, Česká architektura 1956-1963 (pozn. 9).

18 Ibidem, s. 245.

19 Havránek et al., Bruselský sen (pozn. 3). - Strakoš, Po sorele brusel (pozn. 3). - Švácha, Česká architektura 1956-1963 (pozn. 9), s. 39-52.

20 Strakoš, Po sorele brusel (pozn. 3). 
šlení například na plaveckém stadionu v Podolí od Richarda Podzemného (návrh 1958, realizace 1960-1966), na vstupní budově Karolina od Jaroslava Fragnera (1963-1968) a podobně.

Právě s rostoucím uvolněním inspiračních zdrojů a se stále novými technickými možnostmi v průběhu šedesátých let se postupně architektonická produkce přikláněla $\mathrm{k}$ brutalismu a technicismu, které plně rozvíjela především mladší generace architektů začínajících s projektováním až po válce. Konec funkcionalismu v ČSR by tedy mohl být spojen s koncem kariéry meziválečných architektů. Jejich žáci a nástupci již hledali vlastní výraz, tak jako tomu bylo i jinde v Evropě.

Pro srovnání těchto několika vývojových fází funkcionalismu je zajímavé si prohlédnout výkladní skříně Československa, pavilony na světových výstavách - vrcholně funkcionalistický objekt od Jaromíra Krejcara v Pařiži 1937, v roce 1939 v New Yorku pavilon od Kamila Roškota a Jaroslava Polívky s hmotnějším a monumentálnějším výrazem a Cubrův, Hrubého a Pokorného kultivovaný pavilon v Bruselu v roce 1958, který s sebou přinesl posun stylu k novým materiálům, a přesto jasně mluví o comebacku funkcionalistické tradice.

Propojíme-li funkcionalistické fragmenty v poválečné architektuře s životy a tvorbou architektů projektujících již od meziválečného období, nabídne se nám linie vývoje českého funkcionalismu, která přetrvala válku, ale i přerušení a potlačování během padesátých let. Dá se tedy v padesátých letech jistě mluvit o vývoji paralelní tradice, socialistického realismu a funkcionalismu. Funkcionalismus byl v tomto období extrémně oslaben, ale přesto nezmizel a neskončil a spolu s architekty, kteří zažili jeho vrcholné meziválečné období, mohl ještě s posledním vzepětím završit svůj vývoj po roce 1958. Myslím, že skutečný závěr funkcionalismu bychom tedy mohli klást do šedesátých let, kdy byl teprve přirozeně vystřídán novými architektonickými směry.

\section{SUMMARY}

\section{Functionalism in architecture - the interwar phenomenon or the style overcoming war and socialist realism?}

The Functionalism is strictly connected with interwar period in Czechoslovak architecture. There is assumption that the architectural style ended because of the war. However, short episode of so called late functionalism took place after war in 1945-1948. The second ending of functionalist style is placed in the year 1948 when communists took power in Czechoslovakia and politically forced style called socialist realism was adopted. The political situation, which influenced art and architecture deeply, started to loosen in the half of the 1950s and the rise of modernism began. Its symbol in architecture was the Czechoslovak pavilion at international exhibition Expo 58 in Brussels by architects František Cubr, Josef Hrubý, and Zdeněk Pokorný. New generation of architects was influenced by western examples of International style, brutalism, structuralism etc. but older generation was made of architects who worked in the 1920s and the 1930s in the functionalist style and after year 1958 they could return to their functionalist path. 
We can compare the architectural development in Czechoslovakia to the western architecture, where the International style was developed from functionalism and faded in the 1960s together with last works of its interwar representatives (as Ludwig Mies van der Rohe). The situation was more complicated in Czechoslovakia, however the true end (or fading away) of functionalist style, its ideas and aesthetic could be placed in the 1960s.

\section{VÝBĚROVÁ BIBLIOGRAFIE}

Miroslav Baše et al., Česká architektura / Czech architecture 1945-1995, Praha 1995.

Vladimír Czumalo, Česká teorie architektury v letech okupace, Praha 1991.

Český funkcionalismus 1920-1940. Architektura (katalaog výstavy, text Alena Vondrová), Uměleckoprůmyslové muzeum v Praze, Praha 1978.

Jaroslav Fragner: Náčrty a plány (katalog výstavy), Galerie Jaroslava Fragnera, Praha 1999.

Vít Havránek et al., Bruselský sen: Československá účast na světové výstavě Expo 58 v Bruselu a životní styl 1. poloviny 60. let (katalag výstavy), Galerie hlavního města Prahy - Moravská galerie v Brně, Praha-Brno 2008.

Marie Judlová (ed.), Ohniska znovuzrození: České umění 1956-1963 (katalog výstavy), Galerie hlavního města Prahy, Ústav dějin umění AV ČR, Praha 1994.

Petr Pelčák - Vladimír Šlapeta - Ivan Wahla (eds), Bedřich Rozehnal 1902-1984 (katalog výstavy), Obecní dům, Brno 2009.

Radomíra Sedláková (ed.), Sorela: Česká architektura padesátých let (katalog výstavy), Národní galerie v Praze, Praha 1994.

Martin Strakoš, Po sorele brusel: kov, sklo, struktury a beton. Kapitoly o architektuře a umění 50. a 60. let 20. století od Bruselu po Ostravu, Ostrava 2014.

Vladimír Šlapeta - Václav Jandáček, Stavební kniha: Český funkcionalismus, Brno 2004.

Odřich Ševčík - Ondřej Beneš, Architektura 60. let. „Zlatá šedesátá léta“ $v$ české architektuře 20. století, Praha 2009.

Rostislav Švácha, Od moderny k funkcionalismu, Praha 1985, 1995. 


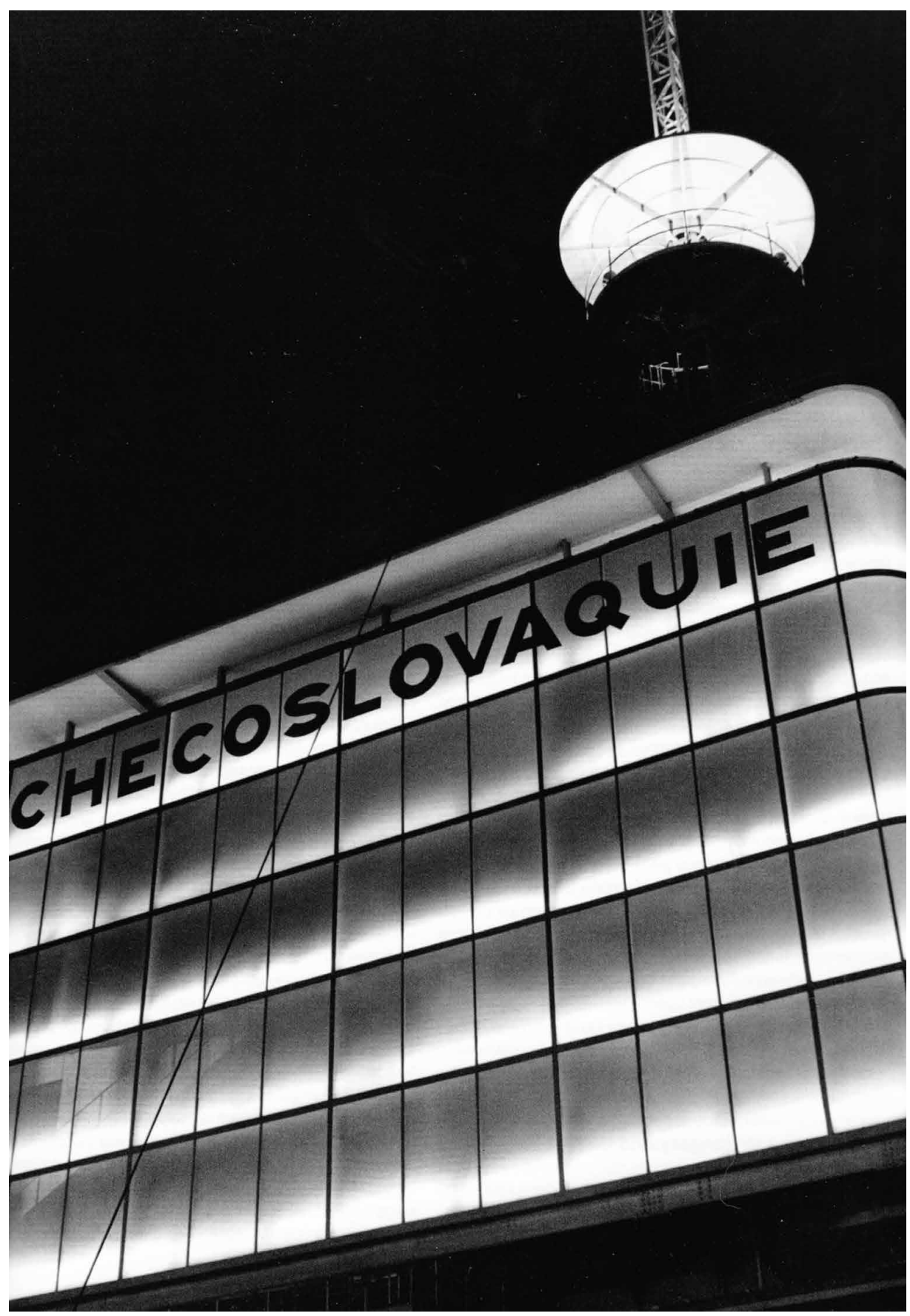

Obrázek 1. Jaromír Krejcar, pavilon ČSR na Mezinárodní výstavě v Paříži 1937. Foto Hugo Herdeg, reprodukce z knihy Jaromír Krejcar 1895-1949 (katalag výstavy), Galerie Jaroslava Fragnera, Praha 1995, s. 133 


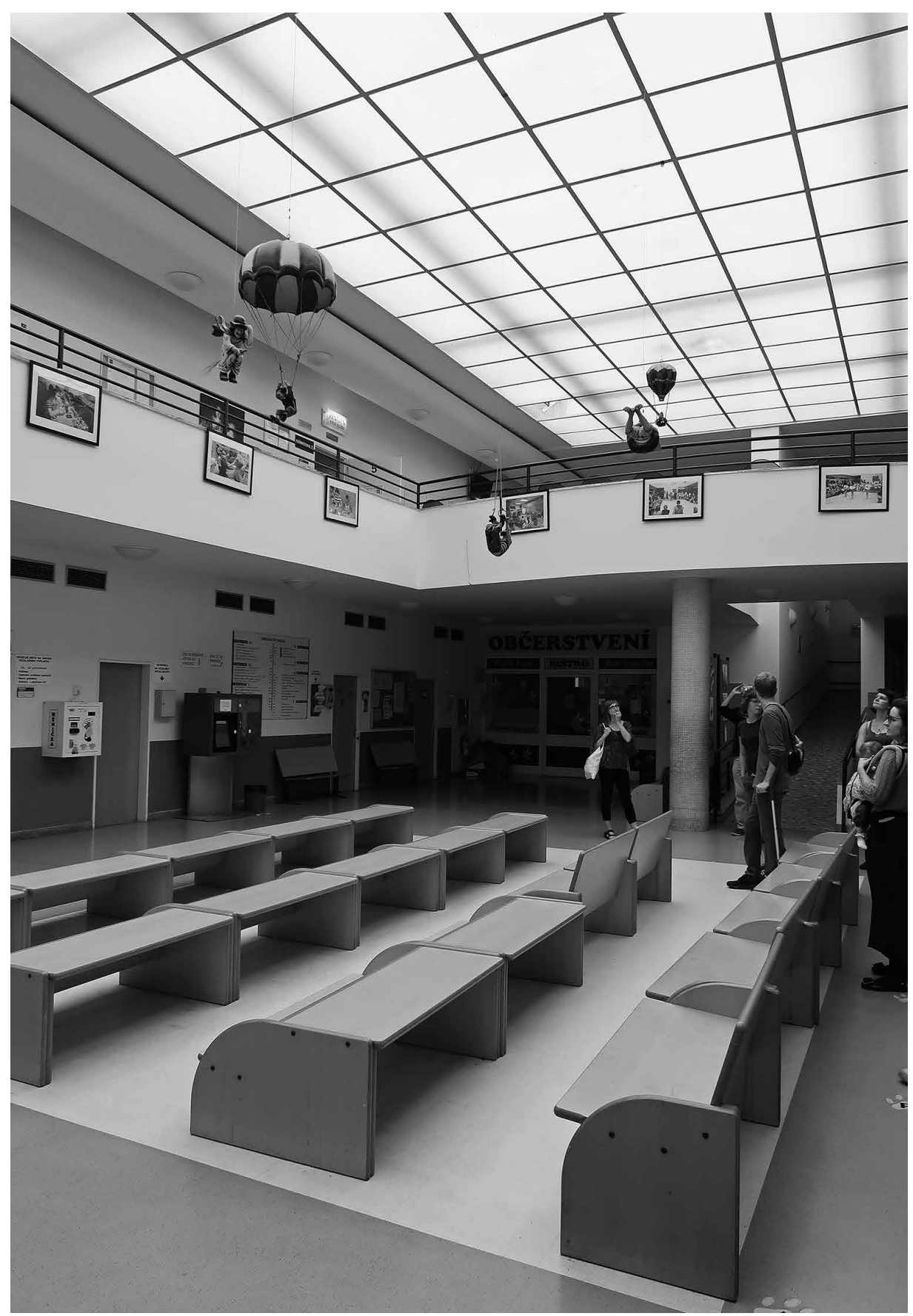

Obrázek 2. Bedřich Rozehnal, dvorana dětské nemocnice v Brně-Černých Polích, 1948-1953. Snímek Rostislav Švácha 


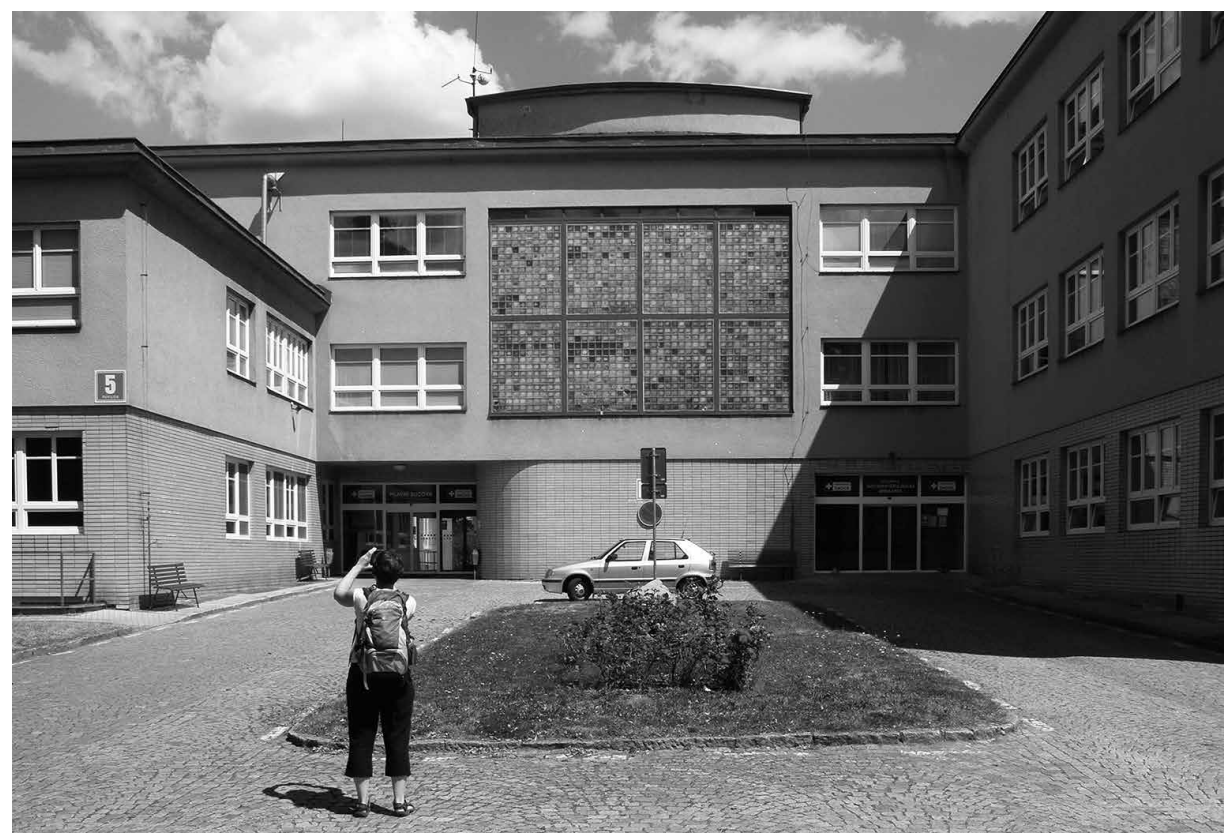

Obrázek 3. Bedřich Rozehnal, obvodní nemocnice v Dačicích, 1945-1951. Snímek Rostislav Švácha

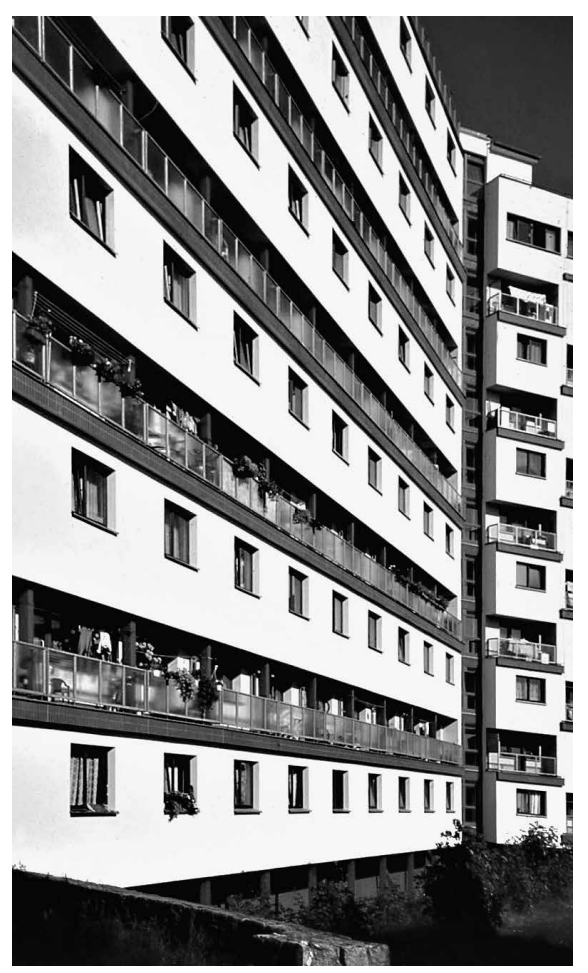

Obrázek 4. Evžen Linhart - Václav Hilský, kolektivní dům v Litvínově, 1948-1958. Snímek Rostislav Švácha 


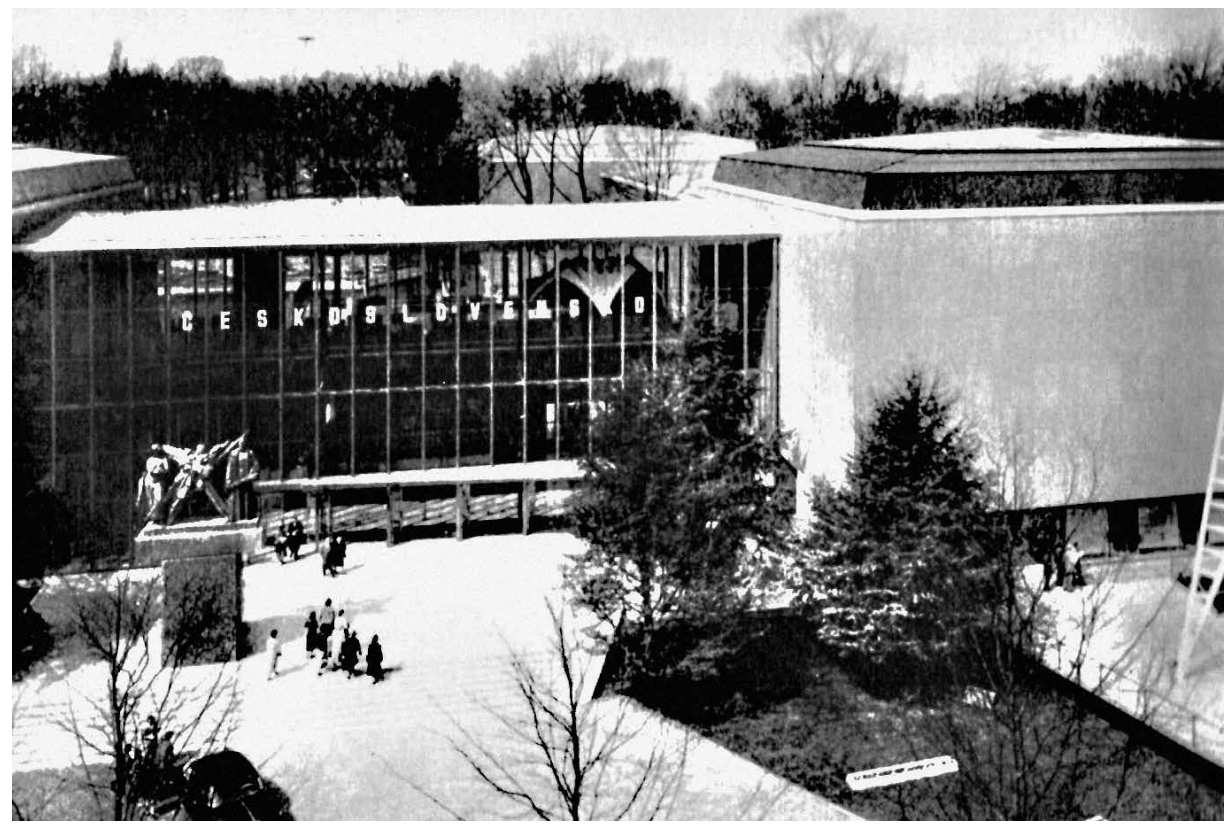

Obrázek 5. František Cubr - Josef Hrubý - Zdeněk Pokorný, československý pavilon pro Expo 58 v Bruselu, 1956 - 1958. Reprodukce z knihy Rika Devos - Mil de Kooning (eds), L'Architecture Moderne à l'Expo 58, Bruxelles 2006, s. 280

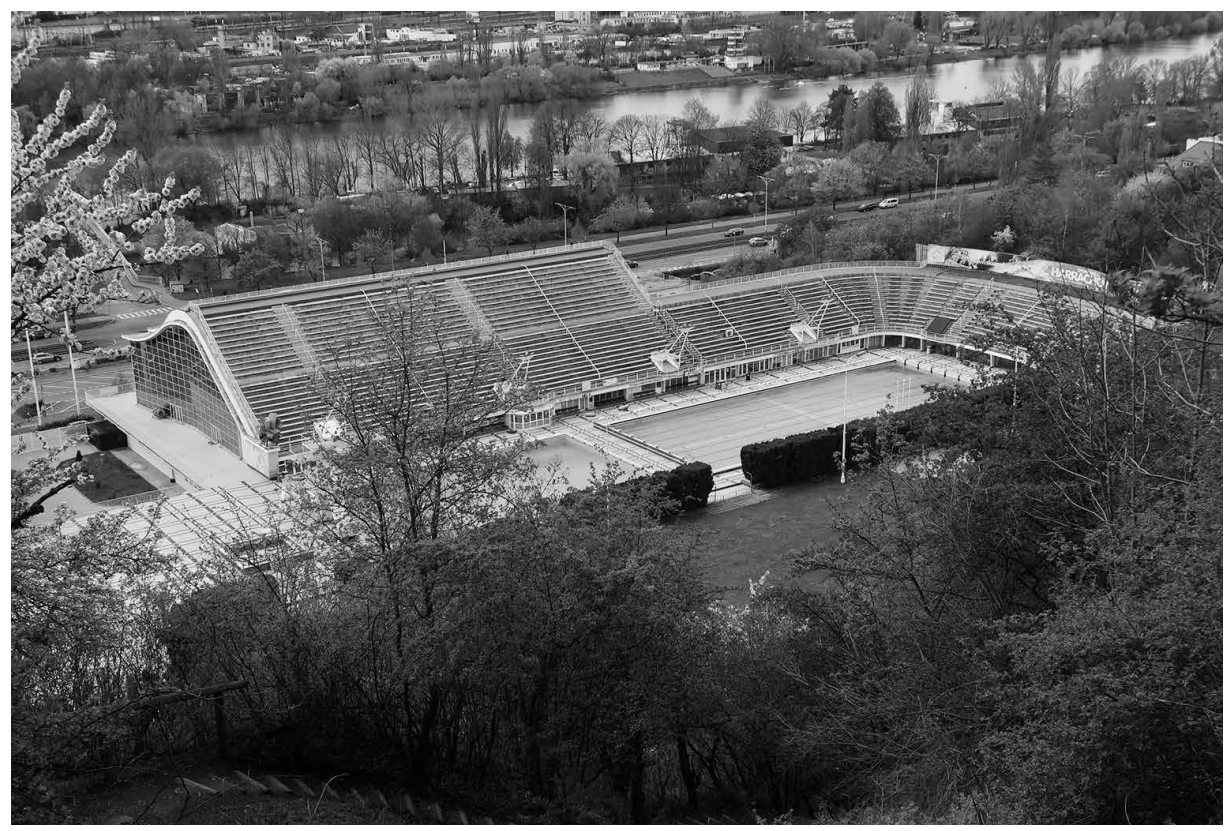

Obrázek 6. Richard Ferdinand Podzemný, Plavecký pavilon v Podolí, Praha, 1958-1965, snímek Rostislav Švácha 


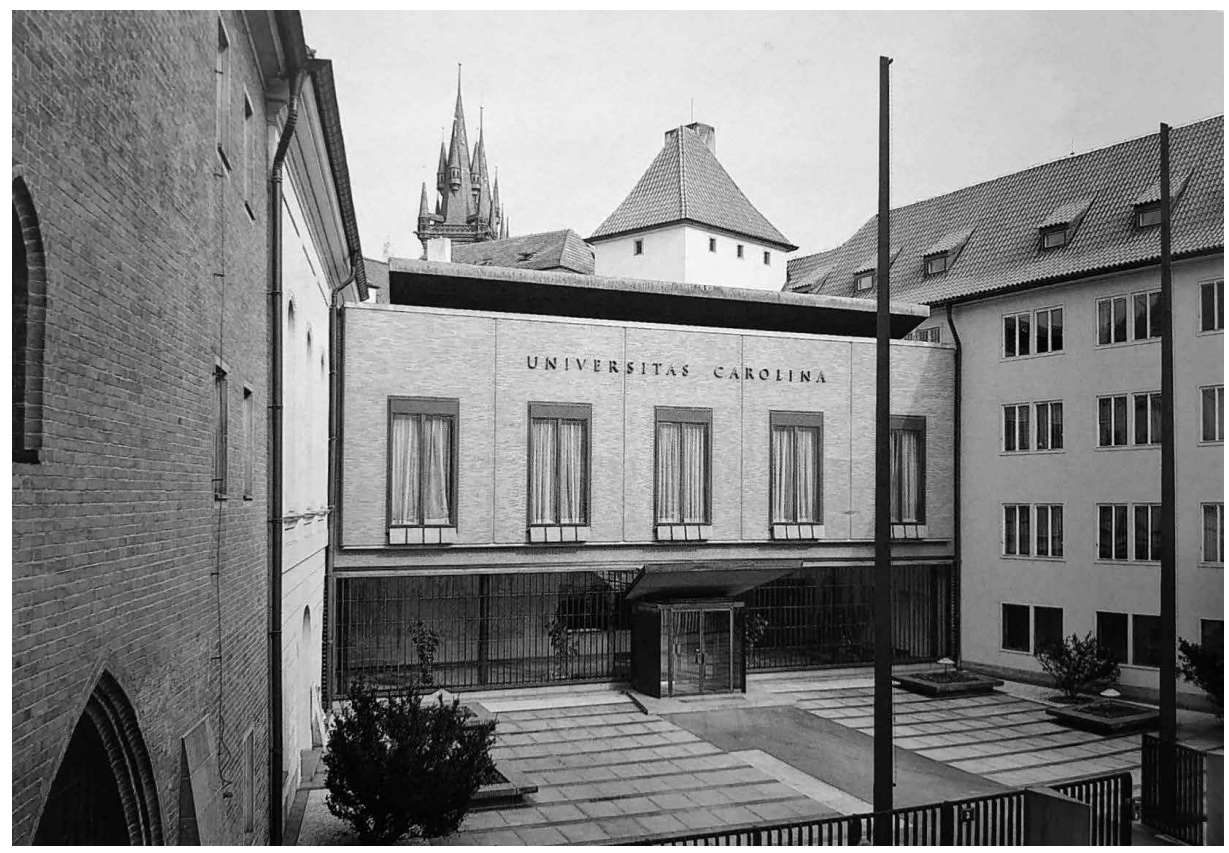

Obrázek 7. Jaroslav Fragner, vstupní budova Karolina v Praze, 1963-1968, reprodukce z knihy Ohniska znovuzrození: České umění 1956-1963 (katalog výstavy), Galerie hlavního města Prahy, Ústav dějin umění AV ČR, Praha 1994, s. 24. 